Volume 2 Nomor 2, Desember 2019

E-ISSN : 2655-7347

\title{
ANALISIS YURIDIS PERTIMBANGAN HAKIM DALAM KASUS JUAL- BELI YANG DIKENAKAN PASAL 480 KUP (STUDI KASUS: PUTUSAN NOMOR 1291/PID.B/2018/PN.JKT.PST)
}

\author{
Hendy \\ (Mahasiswa Program S1 Fakultas Hukum Universitas Tarumanagara) \\ (E-mail: hendywu05@yahoo.com)
}

Firman Wijaya

(Dosen Fakultas Hukum Universitas Tarumanagara. Meraih Sarjana Hukum pada Fakultas.Hukum Universitas.Tarumanagara, Magister.Hukum pada Fakultas Hukum Universitas.Tarumanagara)

(E-mail: firmanwijaya@fh.untar.ac.id)

\begin{abstract}
Dewi Sri Astuti, initially she was only trying to increase financial resources in the family, but she tripped over a case experienced by her business partners, namely Suherman and Susanti. Dewi Sri Astuti was charged guilty because she had purchased items resulting from the theft of a crime committed by her business partners in the place where they worked. Even though Dewi Sri Astuti did not know that the goods she had received from her business partners were the result of a criminal act of theft. In this case to be able to convict someone must be fulfilled two things, namely as actus reus (physical element) and.mens.rea (mental element). However, Dewi Sri Astuti was still found guilty even though it did not fulfill the subjective element of the crime. How is the juridical analysis of buying and selling actions that are subject to article 480 of the Criminal Code (case study: verdict number 1291 / Pid.B / 2018 / PN.JKT.PST)? The author used normative legal methods and used interview data as supporting data. The.results of the study revealed that Dewi Sri Astuti did not fulfill all the elements in Article.480 of the Criminal.Code, where in the element of criminal offense there are 2 (two) elements. First.element is an objective element and.the second element.is a subjective element.
\end{abstract}

Keywords: article 480 of the Criminal Code, Receiving Stolen Property, Publishing and Printing, criminal act of theft.

\section{PENDAHULUAN}

\section{A. Latar Belakang}

Setiap manusia pasti tidak luput dari kebutuhan. Dari kebutuhan yang sederhana hingga kebutuhan yang rumit lainnya. Untuk memenuhi kebutuhan tersebut, masyarakat kita melakukan suatu perbuatan, yaitu perbuatan atau transaksi jual beli. Transaksi jual beli dilakukan untuk mendapatkan barang yang diinginkan. Hubungan jual beli di dalam masyarakat merupakan hubungan 
Volume 2 Nomor 2, Desember 2019 E-ISSN : 2655-7347

keperdataan, karena di Indonesia hubungan tersebut diatur dalam hukum perdata, yang bermaksud supaya tidak ada pihak maupun orang yang dicurangi atau ditipu.

Transaksi jual beli dapat terjadi apabila adanya perjanjian antara dua orang atau lebih. Pasa1 1313 Kitab Undang-Undang Hukum Perdata disingkat "KUHPerdata". perjanjian adalah suatu perbuatan dengan mana satu orang atau lebih mengikatkan dirinya terhadap satu orang lain atau lebih. ${ }^{1)}$

Syarat perjanjian tertuang dalam Pasa1 1320 KUHPerdata, yaitu:

1. sepakatan mereka yang mengikatkan dirinya;

2. kecakapan untuk membuat suatu perikatan;

3. suatu hal tertentu;

4. suatu sebab yang halal.

Pada zaman modern ini, teknologi sudah sangat berkembang dibandingkan dengan zaman dahulu. Setiap kegiatan manusia telah dipermudah dengan bantuan teknologi masa kini. Akan tetapi, dalam perkembangan teknologi tersebut, terdapat sisi negatif yang membuat perbuatan kejahatan semakin beragam dan kompleks. Seperti kasus yang menimpa Dewi Sri Astuti, awalnya dia hanya berusaha untuk meningkatkan sumber keuangan di dalam keluarga, akan tetapi dia tersandung kasus yang dialami oleh rekan bisnisnya, yaitu Suherman dan Susanti. Dewi Sri Astuti dikenakan Pasa1 penadahan dikarenakan dia telah membeli barang hasil tindak pidana pencurian yang dilakukan oleh rekan bisnisnya di tempat mereka bekerja. Padahal Dewi Sri Astuti tidak mengetahui barang yang ia peroleh dari rekan bisnisnya terserbut merupakan hasil tindak pidana pencurian.

Dewi Sri Astuti yang merupakan seorang pengusaha muda berumur 25 tahun, bertempat tinggal di Jalan N. Bhakti RT.009/RW.06, Kelurahan Cilincing, Jakarta Utara yang dulunya bekerja dengan orang lain mencoba membuka usaha sendiri. Setelah mendapat pengalaman bekerja di tempat lamanya, dia merasa percaya diri untuk memulai usaha sendiri. Memulai suatu usaha sendiri pastinya tidak mudah,

\footnotetext{
1) Subekti dan Tjitrosudibio, Kitab Undang-Undang Hukum Perdata, Cetakan ke-41, (PTBalai Pustaka, 2015), hal. 338.
} 
Volume 2 Nomor 2, Desember 2019

E-ISSN : 2655-7347

karena memulai usaha baru memerlukan tekad, modal dan pengalaman yang cukup.

Dewi Sri Astuti yang baru merintis usaha selama (2) dua tahun terpaksa tutup karena dia dinyatakan bersalah karena telah melakukan perbuatan pidana penadahan sebagaimana yang telah diputus oleh Pengadilan Negeri Jakarta Pusat, dengan putusan yang bernomor 1291/Pid.B/2018/PN.JKT.PST.

Adapun jaksa penuntut umum membawa Dewi Sri Astuti ke pengadilan hanya berdasarkan pada asumsi bahwa Dewi Sri Astuti telah membeli barang dari Suherman dan Susanti dengan harga di bawah pasaran, yang ternyata dalam proses persidangan tidak terbukti demikian. Jaksa penuntut umum hanya berdasarkan pada harga Toko Noah, padahal harga barang yang dijual pada Toko Noah bersifat tidak tetap, karena dipengaruhi oleh kurs mata uang asing (USD), promosi dan permintaan pasar.

Kebanyakan orang menginginkan harga yang terendah dalam membeli suatu barang. Tawar menawar merupakan suatu budaya yang terdapat dalam masyarakat. Tidak jarang calon pembeli berpindah toko hanya untuk menemukan harga yang paling murah. Begitupula dengan Dewi Sri Astuti. Dewi Sri Astuti merupakan seorang pelaku bisnis, sangat wajar apabila Dewi Sri Astuti berusaha mencari distributor dengan harga terendah guna memperoleh keuntungan dalam usahanya.

Bahkan tiap kali Dewi Sri Astuti ingin memesan barang dari Suherman, Dewi Sri Astuti selalu mencari perbandingan harga di toko lainnya untuk akhirnya memilih barang dengan harga terendah. Bagaimana dengan orang lain selain Dewi Sri Astuti yang mencari harga terendah suatu barang dapat dianggap sebagai penadahan Jika memang harga terendah dijadikan patokan, maka seharusnya kita semua bergantian duduk di kursi pesakitan seperti Dewi Sri Astuti.

Seperti yang kita ketahui, Indonesia adalah negara hukum, tercantum dalam Pasa1 1 Ayat (3) Undang-Undang Dasar Negara Republik Indonesia disingkat “UUD NRI 1945". 
Volume 2 Nomor 2, Desember 2019

E-ISSN : 2655-7347

Unsur-usur terpenting negara hukum yaitu:

1. Adanya Undang-Undang Dasar sebagai peraturan tertulis yang mengatur hubungan antara pemerintah dan warganya;

2. Adanya pembagian kekuasaan dalam negara (machtenscheiding) yang dengan khusus menjamin suatu kekuasaan kehakiman yang bebas intervensi, sehingga adanya pengawasan dari badan-badan peradilan (rechtelijke controle).

3. Adanya pemencaran kekuasaan negara atau pemerintah (spreading van de staatsmacht);

4. Terjaminnnya hak-hak asasi manusia (warga negara);

5. Ada jaminan persamaan di muka hukum dan jaminan perlindungan hukum;

6. Ada asas legalitas, pelaksanaan kekuasaan pemerintah harus didasarkan atas hukum, dengan kata lain bahwa pemerintah dalam melaksanakan tugas dan kewajibannya berdasar atas hukum atau peraturan perundangundangan. $^{2)}$

Tujuan dari keberadaan hukum yaitu agar masyarakat tertib sehingga tercapainya keadilan dan kedamaian menurut L.J. Apeldoorn. ${ }^{3)}$ Hukum memberi pelayanan kepada masyarakat sehingga tercipta suatu ketertiban, keamanan, keadilan dan kesejahteraan. Maka ketika menjalankan kehidupan bernegara tersebut salah satunya dengan penanganan dalam menyelesaikan masalah sosial yang disebut tindak pidana. Dalam hal ini untuk dapat dipidananya seseorang harus dipenuhi dua hal yaitu actus reus (physical element) dan mens rea (mental element). ${ }^{4)}$

\footnotetext{
2) Anwar, Teori dan Hukum Konstitusi, Cet ke-3, (Malang: Setara Press, 2015), hal. 57.

3) R. Soeroso, Pengantar Ilmu Hukum. Cet ke-11, (Jakarta: Sinar Grafika, 2009), hal. 57.

4) Zainal Abidin Farid, Hukum Pidana 1, (Jakarta, Sinar Grafika, 2014), hal. 35.
} 
Volume 2 Nomor 2, Desember 2019 E-ISSN : 2655-7347

Suatu perbuatan yang dapat dipidana adalah tindak pidana ${ }^{5)}$ atau disebut juga dengan delik (strafbaarfeit) yaitu "Perbuatan manusia yang melakukan kesalahan serta melawan hukum dapat dipidana, yang tercantum dalam Undang-Undang", $\left.{ }^{6}\right)$ Tindak pidana yang salah satunya yaitu penadahan menurut Kitab UndangUndang Hukum Pidana atau yang disingkat dengan "KUHP" yang diatur dalam Bab XXX, Buku II tentang Kejahatan.

Tidak ada pengertian kejahatan penadahan dalam KUHP, akan tetapi pengertiannya bisa ditemukan di Pasa1 480 KUHP, Bab XXX, Buku II Pasa1 480 KUHP menyatakan bahwa:

Diancam dengan penjara paling lama 4 (empat) tahun atau pidana denda paling banyak 9 (sembilan) ratus rupiah:

1. Barang siapa membeli, menyewa, menukar, menerima gadai, menerima hadiah, atau untuk menarik keuntungan, menjual, menyewakan, menukarkan menggadaikan, mengangkut, menyimpan atau menyebunyikan sesuatu benda, yang diketahui atau sepatutnya harus diduga bahwa diperoleh dari kejahatan penadahan.

2. Barangsiapa menarik keuntungan dari hasil sesuatu benda, yang diketahuinya atau harus sepatutnya diduga bahwa diperoleh dari kejahatan. $^{7)}$

Unsur tindak pidana penadahan terdiri dari unsur obyektif dan subyektif seperti yang dikemukakan oleh PAF Lamintang yaitu sebagai berikut:

1. Unsur objektif:

a. Membeli, menyewa, menukar, menerima gadai, menerima hadiah;

b. Untuk mendapat keuntungan;

c. Menjual, menyewakan, menukarkan, menggadai, mengangkut, menyimpan atau menyembunyikan;

5) Wirjono Prodjodikoro, Tindak-Tindak Pidana Indonesia, (Bandung: Eresco, 2004), hal. 1.

6) Andi Hamzah, Asas-Asas Hukum Pidana. Cet. Ke-4, (Jakarta: PT Rienka Cipta, 2010), hal. 96.

7) Andi Hamzah, KUHP \& KUHAP. Cet. Ke-17, (Jakarta: PT Rienka Cipta, 2011), hal. 190. 
Volume 2 Nomor 2, Desember 2019

E-ISSN : 2655-7347

d. Sesuatu barang;

e. Mengambil keuntungan dari hasil penjualan.

2. Unsur subjektif:

a. Yang diketahui atau sepatutnya harus diduga;

b. Bahwa barang itu diperoleh dari kejahatan. ${ }^{8)}$

Seperti yang sudah dijelaskan sebelumnya bahwa Indonesia adalah negara yang berladasan hukum, dengan ciri-ciri dari negara berlandasan hukum adalah memiliki badan peradilan dan juga terjaminnya hak-hak asasi manusia yang tedapat di dalam UUD NRI 1945 yang di mana sangat menjunjung tinggi hak-hak asasi manusia yang khusus terdapat pada Bab XA mengenai Hak Asasi Manusia.

Negara Indonesia tidak lagi menggunakan hukum rimba untuk menangulangi kejahatan, melainkan Negara Indonesia menggunakan dasar pendekatan sistem yaitu sistem peradilan pidana (criminal justice system) dengan dasar open system yang berarti bahwa suatu sistem yang di dalam gerakan mencapai tujuan baik tujuan jangka pendek (resosialisasi), jangka menegah (pencegahan kejahatan) maupun jangka panjang (kesejahteraan sosial) dengan pengaruh dari lingkungan masyarakat dan bagian dalam kehidupan masyarakat, sistemasi peradilan pidana bergerak dan mengalami interface.

Komponen-komponen yang bekerjasama dalam sistemasi peradilan pidana ini, berdasarkan Kitab Undang-Undang Hukum Acara Pidana selanjutnya disingkat "KUHAP" adalah Kepolisian, Kejaksaan, Pengadilan, dan Lembaga Pemasyarakatan. Keempat komponen ini bekerjasama membentuk sistem peradilan pidana terpadu atau integrated criminal justice system. Berjalannya keempat komponen tersebut bertujuan untuk mencari kebenaran. Kebenaran yang dicari merupakan kebenaran materiil yang berasal dari alat bukti. Untuk menentukan

\footnotetext{
${ }^{8)}$ R. Soesilo, Kitab Undang-Undang Hukum Pidana (KUHP), (Bogor: Politeia, 1995).
} 
Volume 2 Nomor 2, Desember 2019

E-ISSN : 2655-7347

seseorang bersalah atau tidak dalam persidangan diperlukan pembuktian, dalam Pasa1 184 Ayat (1) KUHAP disebutkan bahwa alat bukti yang sah adalah:

1. Keterangan saksi;

2. Keterangan ahli;

3. Surat;

4. Petunjuk;

5. Keterangan Terdakwa. ${ }^{9}$

Untuk menentukan seseorang bersalah atau tidak dibutuhkan alat bukti tersebut dan untuk menentukan suatu perbuatan adalah tindak pidana atau bukan harus memenuhi unsur actus reus dan mens rea seperti yang sudah dipaparkan sebelumnya di atas, di mana dalam hal ini juga harus memenuhi unsur dari tindak pidana penadahan itu. Maka dari itu judul penulisan ini adalah "ANALISIS PEMBUKTIAN PADA UNSUR NIAT JAHAT TINDAK PIDANA PENADAHAN (Studi Kasus: Putusan Nomor 1291/Pid.B/2018/PN.JKT.PST)”.

\section{B. Perumusan Masalah}

Berdasarkan uraian latar belakang di atas, maka permasalahannya adalah: Bagaimana analisis yuridis mengenai perbuatan jual beli yang dikenakan Pasa1 480 KUHP (studi kasus: putusan nomor 1291/Pid.B/2018/PN.JKT.PST)?

\section{Metode Penelitian}

1. Jenis penelitian

Peter Mahmud Marzuki menjelaskan bahwa penelitian hukum adalah suatu proses untuk menemukan aturan hukum, prinsip-prinsip hukum, maupun doktrin-doktrin hukum untuk menjawab isu hukum yang dihadapi. Jenis penelitian yang digunakan dalam penelitian ini adalah penelitian hukum normatif atau penelitian untuk keperluan akademis.

\footnotetext{
${ }^{9)}$ Eddy Hiariej O.S, Teori \& Hukum Pembuktian, (Jakarta: Erlangga, 2012), hal. 12.
} 
Volume 2 Nomor 2, Desember 2019

E-ISSN : 2655-7347

\section{Sifat Penelitian}

Penelitian ini menggunakan penelitian yang bersifat deskriptif analitis.

Sifat dari penelitian ini melakukan penjelasan terhadap hasil penelitian dengan data yang lengkap dan detail.

3. Jenis Data

Dalam metode penelitian normatif menurut Peter Mahmud, ada 3 sumber penelitian hukum, yaitu terdiri dari bahan hukum, sekunder dan non hukum. ${ }^{10)}$ Jenis bahan hukum yang akan digunakan dalam penelitian ini antara lain sebagai berikut:

a. Bahan Hukum Primer

Bahan hukum primer merupakan bahan hukum yang bersifat autoratif, yaitu mempunyai otoritas, dengan kata lain mengikat atau membuat orang taat pada hukum seperti peraturan perundang-undangan dan putusan hakim. ${ }^{11}$ ) Bahan hukum primer yang digunakan dalam penulisan ini adalah:

1) Undang-Undang Dasar Negara Republik Indonesia Tahun 1945.

2) Kitab Undang-Undang Hukum Pidana.

3) Putusan Nomor 1291/PID.B/2018/PN.JKT.PST

b. Bahan Hukum Sekunder

Bahan hukum sekunder, yaitu semua publikasi tentang hukum yang memberikan penjelasan mengenai bahan hukum primer, diperoleh dengan cara studi dokumen dan mempelajari permasalahan. ${ }^{12}$ ) Bahan hukum sekunder yang digunakan dalam penulisan ini terdiri dari:

1) Literatur yang berkaitan dengan perundang-undangan;

2) Buku yang berkaitan dengan perundang-undangan;

10) Ibid., hal. 181.

11) Ibid.

12) Ibid. 
Volume 2 Nomor 2, Desember 2019

E-ISSN : 2655-7347

3) Hasil penelitian/karya ilmiah yang berkaitan dengan isu hukum yang dihadapi;

4) Majalah/jurnal hukum/artikel isu hukum yang dihadapi;

5) Bahan lainnya yang berkaitan dengan materi dan sumber data yang berasal dari pencarian menggunakan internet.

c. Bahan nonhukum

Bahan nonhukum adalah uraian di luar bahasan hukum yang memperkaya dan memperluas wawasan, memberikan penjelasan dan membantu dalam mengkaitkan pembahasan untuk menyelesaikan permasalahan. ${ }^{13)}$ Bahan nonhukum yang diguanakan dalam penulisan ini yaitu:

1) Kamus Besar Bahasa Indonesia "KBBI";

2) Penelurusan di internet.

4. Pendekatan Penelitian

Berkaitan dengan penelitian normatif, terdapat berbagai macam pendekatan. Peter mahmud Marzuki menjelaskan ada lima cara pendekatan yang dapat digunakan pada penulisan hukum, sebagai berikut:
a) Pendekatan kasus (case approach);
b) Pendekatanperundang-undangan (statute approach);
c) Pendekatan historis (historical approach)
d) Pendekatan perbandingan (comparative approach); dan
e) Pendekatan konseptual (conceptual approach)

Pendekatan kasus atau case approach adalah metode pendekatan penelitian yang digunakan. Hal yang penting adalah ratio decidendi atau alasan seorang hakim untuk sampai kepada putusannya. Metode pendekatan kasus adalah metode yang paling tepat dalam menjawab permasalahan dalam penulisan ini, yang mengkaji tentang analisis yuridis mengenai perbuatan jual beli yang

13) Ibid., hal. 184. 
Volume 2 Nomor 2, Desember 2019

E-ISSN : 2655-7347

dikenakan Pasal 480 KUHP (studi kasus: putusan nomor 1291/Pid.B/2018/PN.JKT.PST).

5. Teknik Analisis Bahan Hukum

Penelitian menggunakan analisa data dengan teknik cara analisis normatif kualitatif. Dalam teknik analisis normatif kualitatif akan dilakukan penarikan kesimpulan dengan logika deduktif. Peter Mahmud Marzuki mengutip ide ahli lainnya yaitu Philipus M. Hadjon.yang menjelaskan metode deduksi di silogisme yang telah diajarkan oleh seorang filsafat Yunani yaitu Aristoteles. Metode deduksi bermula dari pengajuan premis mayor (pernyataan yang bersifat umum). setelah itu diajukan premis minor (bersifat khusus), dan dari dua premis itu kemudian akan diambil suatu kesimpulan atau conclusion. Tetapi, dalam perdebatan hukum, silogisme hukum tidak sesederhana silogisme tradisional.

Penarikan kesimpulan dalam argumentasi hukum dengan logika deduktif akan dilakukan dengan awalan penjelasan hal yang umum, kemudian menarik hal tersebut menjadi kesimpulan yang lebih khusus.

\section{PEMBAHASAN}

\section{A. Analisis Mengenai Dasar.Hukum Jual Beli di Indonesia}

Jual beli adalah perbuatan keperdataan yang berbentuk suatu perjanjian dan di dalam Kitab Undang-Undang Hukum Perdata yang disingkat "KUHPerdata" mengatur dengan jelas hal apa saja yang perlu diketahui oleh para pihak. Perbuatan jual beli dimulai dengan kesepakatan antara satu pihak dengan pihak lainnya atau lebih. Setiap pihak harus melakukan kewajibannya demi tercapainya kesepakatan awal, setelah kesepakatan dicapai barulah mendapatkan hak. Perikatan ialah hubungan hukum antara dua orang atau lebih, 
di mana yang satu berhak menuntut sesuatu hal dari pihak lain, dan pihak yang lain berkewajiban dalam memenuhi tuntutan itu. ${ }^{14)}$

Perjanjian ialah peristiwa seorang berjanji kepada orang lain atau kedua orang itu saling berjanji untuk melaksanakan sesuatu hal, setelah melakukan hal tersebut, maka dapat dikatakan perikatan. Perjanjian.menimbulkan suatu perikatan antara.dua orang yang membuatnya. Dalam. bentuknya, perjanjian itu berupa.suatu.rangkaian perkataan yang mengandung.janji-janji atau kesanggupan.yang diucapkan.atau ditulis. ${ }^{15}$ ) Pasa1 1313 KUHPerdata menjelaskan perjanjian adalah suatu perbuatan dengan mana satu orang atau lebih mengikatkan dirinya terhadap satu orang lain atau lebih. ${ }^{16)}$

Syarat perjanjian tertuang dalam Pasal 1320 KUHPerdata, yaitu:

1. Kesepakatan mereka yang mengikatkan dirinya;

2. Kecakapan untuk membuat suatu perikatan;

3. Suatu hal tertentu;

4. Suatu sebab yang halal.

Dua syarat yang pertama adalah syarat subjektif, karena mengenai orang atau subjeknya yang melakukan perjanjian, dua syarat yang terakhir adalah syarat objektif karena mengenai perjanjian atau objek dari perbuatan hukum yang dilakukan itu. ${ }^{17)}$ Kesepakatan harus terjadi terlebih dahulu agar suati perjanjian dapat dikatakan sah. Para pihak harus sepakat memberikan persetujuannya mengenai hal yang terdapat di dalam perjanjian tersebut.

Kata setuju dan sepakat adalah hal yang sangat penting dalam suatu perjanjian. Tanpa ada kata-kata tersebut, maka perjanjian tidak memiliki ikatan bagi para pembuatanya. Setuju dan sepakat dilakukan dengan penuh kesadaran di antara para pembuatnya, yang bisa diberikan secara lisan dan tertulis.

Suatu perjanjian dianggap cacat atau dianggap tidak ada apabila:

14) Subekti, Hukum Perjanjian, Cetakan ke-23, (Jakarta: PT Intermasa, 2010), hal. 1

15) Ibid.

16) Subekti dan Tjitrosudibio, Kitab Undang-Undang Hukum Perdata, Cetakan ke-41, (PT Balai Pustaka, 2015), hal. 338.

17) Subekti, Op cit., hal. 17. 
1. mengandung paksaan (dwang), termasuk tindakan atau ancaman atau intimidasi mental.

2. mengandung penipuan (bedrog), adalah tindakan jahat yang dilakukan salah satu pihak, misal tidak menginformasikan adanya cacat tersembunyi.

3. mengandung kekhilafan/kesesatan/kekeliruan (dwaling), bahwa salah satu pihak memiliki persepsi yang salah terhadap subyek dan obyek perjanjian. Terhadap subyek disebut error in persona atau kekeliruan pada orang, misal melakukan perjanjian dengan seorang artis, tetapi ternyata perjanjian dibuat bukan dengan artis, tetapi hanya memiliki nama dengan artis. Terhadap obyek disebut error in substantia atau kekeliruan pada benda. Seperti membeli batu permata, ketika sudah dibeli, ternyata batu permata tersebut palsu.

Pasa1 1329 KUHPerdata menyatakan bahwa setiap orang adalah cakap untuk membuat perjanjian, kecuali apabila menurut undang-undang dinyatakan tidak cakap. Kemudian Pasa1 1330 KUHPerdata menyatakan bahwa ada beberapa orang yang tidak cakap untuk membuat perjanjian, yakni:

1. Orang yang belum dewasa (dibawah dua puluh satu tahun, kecuali yang ditentukan lain);

2. Mereka yang ditaruh di bawah pengampuan (curatele or conservatorship);

3. Perempuan yang sudah menikah.

Dewi Sri Astuti yang merupakan seorang pengusaha muda berumur 25 tahun, bertempat tinggal di Jalan N. Bhakti RT.009/RW.06, Kelurahan Cilincing, Jakarta Utara mulai merintis usaha sendiri dengan membuka sebuah toko, toko yang dibuka adalah toko barcode scanner. Dewi Sri Astuti sebelum membuka tokonya sendiri, dia telah bekerja di toko yang serupa, sehingga dia memiliki pengalaman yang cukup di bidang elektronik khususnya alat-alat barcode scanner ini. Setelah menjalani usahanya selama kurang lebih dua (2) tahun, dia tersandung kasus yang dilakukan oleh teman rekan kerjanya di toko dahulu Dewi Sri Astuti bekerja. Dewi Sri Astuti dinyatakan bersalah karena telah melakukan tindak pidana penadahan sebagaimana yang telah diputus oleh 
Volume 2 Nomor 2, Desember 2019

E-ISSN : 2655-7347

pengadilan Negeri Jakarta Pusat, dengan putusan Nomor 1291/Pid.B/2018/PN.JKT.PST. Putusan pengadilan Negeri Jakarta Pusat menyatakan Dewi Sri Astuti telah melakukan tindak pidana penadahan, karena telah membeli barang yang lebih murah dari pasaran, dan barang tersebut berasal dari tindak pidana pencurian/penggelapan yang dilakukan oleh rekan kerjanya di toko dahulu ia bekerja, yaitu Suherman dan Susanti.

Adapun jaksa penuntut umum membawa Dewi Sri Astuti ke pengadilan hanya berdasarkan pada asumsi bahwa Dewi Sri Astuti telah membeli barang dari Suherman dan Susanti dengan harga di bawah pasaran, yang ternyata dalam proses persidangan tidak terbukti demikian. Jaksa penuntut umum hanya berdasarkan pada harga Toko Noah, padahal harga barang yang dijual pada Toko Noah bersifat tidak tetap, karena dipengaruhi oleh kurs mata uang asing (USD), promosi dan permintaan pasar.

Harga pasaran yang seharusnya tidak berpatokan pada satu toko saja, dalam kasus ini hanya berpatokan pada harga Toko Noah tidaklah tepat. Bagaimana bisa dikatakan harga pasaran sedangkan harga yang dipakai adalah harga dari 1 toko saja. Harga pasaran merupakan harga yang beredar dalam pasaran, diambil dari harga beberapa toko yang terdapat di suatu wilayah sehingga mendapat gambaran angka dari harga barang tersebut. Dewi Sri Astuti sebagai seorang pengusaha pasti melakukan transaksi jual beli terhadap konsumen, begitu juga Dewi Sri Astuti dengan penyedia stok barang. Dewi Sri Astuti membandingkan harga dari satu penjual dengan penjual lain demi mendapatkan harga yang paling murah diantara beberapa penjual.

Pada saat itu Suherman dan Susanti yang dikenal oleh Dewi Sri Astuti sebagai karyawan dari Toko Noah memiliki barang yang lebih murah dari penjual-penjual lainnya, sehingga terjadilah transaksi jual beli yang sewajarnya tidak disangka oleh Dewi Sri Astuti bahwa barang yang dibeli adalah barang dari hasil penggelapan dari Toko Noah dimana Suherman dan Susanti bekerja. Dewi Sri Astuti tidak menaruh curiga sama sekali karena sebelumnya telah 
Volume 2 Nomor 2, Desember 2019

E-ISSN : 2655-7347

mengenal Suherman dan Susanti karena mereka adalah teman mitra kerja di tempat lama Dewi Sri Astuti bekerja, dan Dewi Sri Astuti membeli barang yang diduga oleh dia adalah barang yang berasal dari toko Noah tersebut. Hal ini seharusnya tidak memenuhi unsur subjektif didalam Pasa1 480 KUHP mengenai penadahan, yaitu:

1. Barangsiapa membeli, menyewa, menukar, menerima gadai, menerima hadiah, atau untuk menarik keuntungan, menjual, menyewakan, menukarkan, menggadaikan, mengangkut, menyimpan atau menyebunyikan sesuatu benda, yang diketahui atau sepatutnya harus diduga bahwa diperoleh dari kejahatan penadahan.

2. Barangsiapa menarik keuntungan dari hasil sesuatu benda, yang diketahuinya atau harus sepatutnya diduga bahwa diperoleh dari kejahatan. Unsur tindak pidana penadahan terdiri dari unsur obyektif dan subyektif seperti yang dikemukakan oleh PAF Lamintang yaitu sebagai berikut:

3. Unsur objektif:

a. Membeli, menyewa, menukar, menerima gadai, menerima hadiah;

b. Untuk mendapat keuntungan;

c. Menjual, menyewakan, menukarkan, menggadai, mengangkut, menyimpan atau menyembunyikan;

d. Sesuatu barang;

e. Mengambil keuntungan dari hasil penjualan.

4. Unsur subjektif:

f. Yang diketahui atau sepatutnya harus diduga;

g. Bahwa barang itu diperoleh dari kejahatan. ${ }^{18)}$

Transaksi jual-beli yang terjadi di bawah Mangga Dua Mall adalah hal yang lumrah terjadi diantara pelaku usaha dan pihak distributor. Dewi Sri Astuti

${ }^{18)}$ R. Soesilo, Kitab Undang-Undang Hukum Pidana (KUHP), (Bogor: Politeia, 1995). 
Volume 2 Nomor 2, Desember 2019

E-ISSN : 2655-7347

adalah pelaku usaha yang baru mulai merintis usahanya, sehingga dia melakukan transaksi jual beli dalam skala yang masih kecil, maka karena itu dia memesan barang dalam jumlah satuan, dan membayarnya langsung dalam bentuk uang tunai atau cash. Menurut pendapat dosen Hendra, dia berpendapat bahwa Dewi Sri Astuti dapat mentransfer uang hasil pembelian barang langsung ke rekening pemilik toko tersebut. akan tetapi, Dewi Sri Astuti hanya melakukan transaksi secara mikro, sedangkan sebuah toko distributor melakukan transaksi yang secara makro atau dalam jumlah yang besar, Dewi Sri Astuti dapat melakukan transaksi secara kecil atau mikro karena pemilik toko Noah telah mengenal dengan Dewi Sri Astuti sehingga ia dapat melakukan transaksi secara kecil akan tetapi tetap diberikan harga yang sama dengan pelaku usaha lainnya yang mengambil/membeli barang dalam jumlah yang besar atau makro.

Dewi Sri Astuti bukanlah seorang pelaku tindak pidana yang selalu membeli barang hasil-hasil tindak pidana kejahatan untuk dijual kembali demi mendapatkan keuntungan yang sebesar-besarnya. Dewi Sri Astuti adalah seorang pelaku usaha yang melakukan transaksi seperti biasa seperti pelaku usaha lainnya. Menurut pendapat Prof Jaene, seseorang dapat dikatakan sebagai seorang tersangka pelaku tindak pidana penadahan jika orang tersebut memenuhi dua (2) hal, yaitu unsur dapat dipidananya seseorang harus dipenuhi dua hal yaitu actus reus (physical element) dan mens rea (mental element). ${ }^{19)}$

Dewi Sri Astuti seharusnya mendapatkan keadilan dalam proses pengadilan karena perbuatan dia tidak memenuhi unsur actus reus (physical element) karena Dewi Sri Astuti tidak memiliki niat jahat dari awal mulainya transaksi. Seseorang dapat dikatakan penadahan jika memenuhi unsur yang berada didalam Pasa1 480 KUHP seperti membeli barang dalam kondisi yang gelap, tidak jelas, patut diduga bahwa barang tersebut merupakan barang yang

19) Zainal Abidin Farid, Hukum Pidana 1, (Jakarta, Sinar Grafika, 2014), hal. 35. 
gelap. Dalam kasus ini Dewi Sri Astuti tidak memenuhi unsur membeli dalam keadaan yang gelap karena dia bertransaksi di kondisi yang tidak gelap, karena dia membeli barang tersebut dengan cara bagaimana seorang pengusaha di bidang alat barcode scanner, dilakukan di wilayah Mangga Dua Mall dan transaksi dengan pembayaran tunai/cash.

Majelis hakim perpatokan bahwa transaksi yang dilakukan oleh Dewi Sri Astuti dengan rekan kerjanya, yaitu Suherman dan Susanti adalah perbuatan yang tidak sah karena tidak dilengkapi oleh invoice pembelian barang. Faktanya Dewi Sri Astuti selalu meminta invoice dari Suherman dan Susanti, akan tetapi mereka tidak memberikan dengan alasan nanti dibuatkan sekalian. Dalam hal ini dapat disimpulkan bahwa Dewi Sri Astuti merupakan seorang pelaku usaha yang dari awalnya memang tidak memiliki niat jahat, sebagaimana hakim menjatuhkan hukuman kepada Dewi Sri Astuti karena dia tidak memiliki invoice pembelian barang dari Suherman dan Susanti. Sungguh naas nasib Dewi Sri Astuti karena perbuatan yang dilakukan oleh rekan kerjanya, maka dia juga ikut terseret dalam perbuatan yang dilakukan oleh rekan kerjanya. Seharusnya, cukup rekan kerja Dewi Sri Astuti yang memepertanggungjawabkan perbuatan mereka sendiri tanpa menyeret Saudari Dewi Sri Astuti ke dalam kesengsaraan tersebut.

Pembelian barang oleh saudari Dewi Sri Astuti dikatakan dibawah pasaran nyatanya tidak dapat dinyatakan benar, karena harga pasaran yang digunakan oleh jaksa penuntut umum merupakan harga yang berlaku di Toko Noah saja, seharusnya jaksa penuntut umum melakukan survey harga pasar terlebih dahulu, seperti penulis yang mendapatkan harga pasaran dari beberapa toko yang berada di Toko Mangga Dua Mall, dan Penulis juga mengambil data dari E-commerce terpercaya seperti Tokopedia.

\section{B. Analisis Mengenai Unsur Niat Jahat dalam Tindak Pidana Pendahan}


Volume 2 Nomor 2, Desember 2019

E-ISSN : 2655-7347

Seseorang dapat dikatakan sebagai seorang tersangka pelaku tindak pidana penadahan jika orang tersebut memenuhi dua (2) hal, yaitu unsur dapat dipidananya seseorang harus dipenuhi dua hal yaitu actus reus (physical element) dan mens rea (mental element). ${ }^{20)}$ Tersangka Dewi Sri Astuti yang dikenakan Pasa1 480 KUHP harusnya tidak dihukum atas perbuatannya karena menurut Penulis Dewi Sri Astuti tidak memenuhi unsur dari actus reus (physical element). Penerapan pidana tentunya harus sesuai dengan koridor hukum yang berlaku, terdapat sebuah istilah yang berasal negara common law memberikan syarat pemberian nestapa atau penjatuhan pidana terhadap seseorang yaitu: “Actus Non Facit Reum Nisi Mens Sit Rea” yang berarti suatu perbuatan tidak membuat seseorang bersalah, kecuali dengan sikap batin yang salah. Dalam kasus ini, Penulis merasa Dewi Sri Astuti tidak patut merasakan nestapa yang seharusnya cukup rekannya saja yaitu Susanti dan Suherman yang bertanggung jawab atas perbuatan pidananya.

Penulis berpendapat bahwa Dewi Sri Astuti hanyalah seorang pelaku usaha yang melakukan kegiatannya sebagai layaknya seorang pengusaha, bagaimana Dewi Sri Astuti dapat dikatakan bersalah karena dia hanya membandingkan harga-harga yang paling murah diantara penjual-penjual yang dia kenal. Seorang pelaku usaha pasti ingin mendapatkan keuntungan yang sebesarnya demi penghasilan si pelaku usaha sendiri. Majelis hakim menjatuhkan hukuman kepada Dewi Sri Astuti karena dia dianggap membeli barang dibawah harga pasaran. Bagaimana dapat dikatakan harga dibawah pasaran jika harga yang digunakan sebagai acuan adalah harga dari satu toko saja, Penulis merasa putusan Hakim dalam hal ini kurang tepat. Dalam fakta persidangan, Dewi Sri Astuti membeli barang dengan harga yang tidak terpaut jauh dari harga pasaran, harga pasaran yang penulis peroleh dari surat penawaran yang berasal dari beberapa toko yang berada satu tempat dimana pemilik toko yang dirugikan/

20) Zainal Abidin Farid, Hukum Pidana 1, (Jakarta, Sinar Grafika, 2014), hal. 35. 
Toko Noah, yaitu di Mangga Dua Mall dan di E-commerce Tokopedia. Dalam putusan ini, jaksa penuntut umum hanya melihat atau berpatokan satu bukti, yaitu harga atau price list dari satu toko saja.

Tentu saja perbandingan harga pasaran yang diperoleh Penasehat hukum dengan Jaksa penuntut umum berbeda, harga pasaran yang diperoleh dari Penasehat Hukum merupakan harga aktual yang berlaku saat itu juga, hal itu dapat dibuktikan dengan lampiran mengenai surat penawaran yang diperoleh oleh Penasehat hukum memiliki rentan harga yang tidak terpaut jauh dengan harga saat Dewi Sri Astuti membeli barang dari Suherman dan Susanti. Justu Dewi Sri Astuti penah membeli barang lebih mahal dari harga pasaran untuk kemudian dijual kembali kepada konsumen. Penulis berpendapat bahwa harga pasaran yang diperoleh oleh jaksa penuntut umum tidaklah tepat untuk menggambarkan harga pasaran yang belaku saat transaksi jual beli yang berlangsung antara Dewi Sri Astuti dengan saudara Suherman dan Saudari Susanti.

Majelis hakim menjatuhkan hukuman bahwa Dewi Sri Astuti membeli barang dengan harga yang lebih murah, Penulis tidak sependapat dengan keputusan hakim dalam hal ini karena dalam fakta yang terjadi saat Dewi Sri Astuti membeli barang dari saudara Suherman dan Saudari Susanti hanya memiliki perbedaan harga berkisar antara Rp.10.000,00 (sepuluh ribu rupiah) hingga Rp. 50.000,00- (lima puluh ribu rupiah). Tentu saja nominal tersebut sangat kecil dibandingkan dengan hukuman yang diterima oleh Dewi Sri Astuti dan status narapidana yang bakal disandang dia seumur hidup.

Dalam hal ini penulis tidak sependapat dengan keputusan majelis hakim karena menurut penulis keputusan majelis hakim seharusnya menimbang dengan adagium yang sudah ada sejak lama, yaitu: "lebih baik seratus orang yang bersalah dibebaskan dari pada seseorang yang tidak bersalah dihukum”. Dalam hal ini Penulis berpendapat bahwa hakim seharusnya lebih memerhatikan kondisi nasib Dewi Sri Astuti. 
Kesalahan menurut Simons adalah pengertian yang "sociaal- ethisch" yang dapat diartikan sebagai dasar untuk pertanggungjawaban dalam hukum pidana berupa keadaan psikis dari si pembuat dan hubungannya terhadap perbuatannya, serta dalam arti bahwa berdasarkan keadaan psikis (jiwa) itu perbuatannya dapat dicelakan kepada si pembuat. Penulis berpendapat bahwa pengertian Simons mengenai kesalahan sangat tepat, bagaimana Dewi Sri Astuti dapat dinyatakan bersalah jika keadaan psikis Dewi Sri Astuti tidaklah terpenuhi oleh niat jahat.

Pengertian kesalahan dalam hukum pidana dibagi kedalam 3 ciri atau unsur-unsur menurut Vos yaitu dapat dipertanggungjawabkan oleh pelaku, hubungan psikis pelaku dengan perbuatannya yang biasanya dalam bentuk sengaja atau alpa, dan yang terakhir adalah tidak ada dasar-dasar yang menghapuskan pertanggung- jawaban pelaku atas perbuatannya. Penulis berpendapat bahwa Dewi Sri Astuti melakukan transaksi jual beli kepada saudara Suherman dan Susanti memang tidak memiliki unsur niat jahat, karena Dewi Sri Astuti tidak menduga bahwa barang yang ia peroleh dari saudara Suherman dan Susanti merupakan barang dari hasil tindak pidana pencurian/penggelapan dari tempat/ Toko mereka bekerja. Dewi Sri Astuti yang tidak mengetahui barang yang ia peroleh dari rekan kerjanya tersebut merupakan perbuatan tindak pidana pencurian.

Penulis berpendapat bahwa pembuktian berdasarkan keyakinan hakim semata (Conviction in Time) yang diterapkan oleh majelis hakim dalam memutus putusan Dewi Sri Astuti tidaklah tepat. Sistem ini berarti bahwa penilaian dari keyakinan hakim semata menentukan seorang bersalah atau tidak. Keyakinan hakim tidak harus berasal pada alat bukti, melainkan apabila hakim tidak yakin, meskipun alat bukti sudah cukup, maka hakim tidak boleh menjatuhkan pidana, sebaliknya apabila hakim sudah yakin meskipun alat bukti tidak ada, maka Terdakwa dapat dinyatakan bersalah, akibatnya dalam memutuskan perkara hakim menjadi subyektif. 
Kelemahan pada sistem ini yaitu terlalu banyak memberikan kepercayaan kepada hakim, yang memberikan kesan sulit untuk melakukan pengawasan. Hal ini terjadi pada praktik Peradilan Prancis yang membuat pertimbangan putusan bebas yang aneh. Majelis hakim yang memutus putusan Dewi Sri Astuti seharusnya lebih memerhatikan fakta-fakta yang diberikan oleh tim penasehat hukum, dalam putusan ini Majelis hakim seolah-olah mengabaikan bukti-bukti yang disampaikan oleh tim penasehat hukum Terdakwa.

Pembelian barcode scanner oleh Dewi Sri Astuti kepada saudara Suherman dan saudari Susanti adalah dengan cara yang tepat dan wajar, setiap transaksi yang dilakukan oleh Dewi Sri Astuti adalah dengan cara yang wajar dilakukan oleh pebisnis barcode scanner yang berada di wilayah Mangga Dua Mall dan pada umunya. Dewi Sri Astuti membeli barang dari orang yang berkecimpung dalam dunia bisnis barcode, dalam kasus ini Dewi Sri Astuti membeli barang dari saudara suherman dan saudari Susanti yang memang sudah dikenal oleh Dewi Sri Astuti sejak tahun 2010 saat Terdakwa masih bekerja di Toko Arta Muara.

Pemesanan barang yang dilakukan oleh Dewi Sri Astuti melalui Whatsapp Messenger yang dimana hal tersebut merupakan sudah menjadi kebiasaan di wilayah Mangga Dua Mall. Setiap kali Dewi Sri Astuti ingin melakukan pemesanan barang, Terdakwa langsung menghubungi Saudara Suherman melalui chat Whatsapp untuk menanyakan ketersediaan barang dan harga sehingga tercapai kesepakatan pembelian. Pemesanan melalui Whatsapp Messenger tersebut memang sudah lumrah dilakukan oleh setiap toko yang ada di Mangga Dua Mall untuk memudahkan transaksi dan memanfaatkan kemudahan teknologi. Sesuai dengan yurisprudensi Mahkamah Agung RI Nomor: 1130K/PID/1985 tanggal 18 Desember 1987 yang memberikan kaidah hukum yaitu: Apabila Terdakwa tidak mengetahui / menduga / menyangka barang-barang tersebut berasal dari kejahatan, karena itu adalah salah satu unsur 
Volume 2 Nomor 2, Desember 2019

E-ISSN : 2655-7347

dari Pasa1 480 KUHP tidak dapat dibuktikan, maka Terdakwa dalam kasus ini Dewi Sri Astuti harus dibebaskan.

\section{PENUTUP}

\section{A. Kesimpulan}

Berdasarkan analisis yuridis mengenai perbuatan jual beli yang dikenakan Pasa1 480 KUHP (studi kasus: putusan nomor 1291/Pid.B/2018/PN.JKT.PST), Dewi Sri Astuti tidak memenuhi semua unsur dalam Pasa1 480 KUHP, dimana dalam unsur tindak pidana penadahan terdapat 2 (dua) unsur. Unsur yang pertama adalah unsur objektif dan unsur kedua adalah unsur subjektif. Perbuatan yang dilakukan oleh Dewi Sri Astuti memenuhi unsur tindak pidana penadahan objektif, yaitu perbuatan jual beli, namun tidak memenuhi unsur subjektif yaitu mengetahui bahwa barang yang diperoleh adalah hasil dari tindak pidana kejahatan yang dilakukan oleh Suherman dan Susanti, sehingga tidak memenuhi unsur niat jahat / mens rea.

\section{B. Saran}

Bagi penegak hukum seyogyanya lebih bijaksana dalam memutus suatu perkara, harus memerhatikan fakta-fakta yang ada dalam persidangan sehingga tidak merugikan pihak manapun.

\section{DAFTAR PUSTAKA}

\section{A. Buku}

Anwar. Teori dan Hukum Konstitusi. Cet ke-3. (Malang: Setara Press, 2015).

Farid, Zainal Abidin. Hukum Pidana 1. (Jakarta, Sinar Grafika, 2014).

Hamzah, Andi. Asas-Asas Hukum Pidana. Cet. ke-4. (Jakarta: PT Rienka Cipta, 2010).

Hamzah, Andi. KUHP \& KUHAP. Cet. ke-17. (Jakarta: PT Rienka Cipta, 2011). O.S, Eddy Hiariej. Teori \& Hukum Pembuktian. (Jakarta: Erlangga, 2012). 
Volume 2 Nomor 2, Desember 2019

E-ISSN : 2655-7347

Prodjodikoro, Wirjono. Tindak-Tindak Pidana Indonesia. (Bandung: Eresco, 2004).

Subekti. Hukum Perjanjian. Cet ke-23. (Jakarta: PT Intermasa, 2010).

Subekti dan Tjitrosudibio. Kitab Undang-Undang Hukum Perdata. Cet ke-41, (PT Balai Pustaka, 2015).

Soesilo, R. Kitab Undang-Undang Hukum Pidana (KUHP). (Bogor: Politeia, 1995).

Soeroso, R. Pengantar Ilmu Hukum. Cet ke-11. (Jakarta: Sinar Grafika, 2009).

\section{B. Putusan Pengadilan}

Indonesia. Putusan Pengadilan Negeri Jakarta Pusat Nomor 1291/Pid.B/2018/PN.JKT.PST 